\title{
The safety issue of roadside advertising - comparison of Polish and Abu Dhabi regulations
}

\author{
Tomasz Mackun ${ }^{1, *}$, and Joanna Żukowska ${ }^{1}$ \\ ${ }^{1}$ Gdansk University of Technology, Faculty of Civil and Environmental Engineering, Gdansk, Poland
}

\begin{abstract}
In Poland a large number of advertisements are located by the roadside. These ads do not support road traffic management and unlike the road marking system are not subject to any regulations. The advertiser's goal is to communicate a message to as many recipients as possible. Drivers with different individual abilities, such as attention focusing, eye accommodation, speed of information processing, can be distracted, blinded or confused by the content and form of the advertising. There are elements of the road network, such as intersections, pedestrian crossings, road junctions etc. where the driver must assess the situation on the road, predict the behaviour of other users, make decisions and finally complete a manoeuvre. It all happens in a limited span of time when actions should be taken calmly with full attention. It is obvious that the attention of drivers, especially in those zones, should be focused on the task of driving. In this article, the authors present a perspective on selected national laws, and also quote Abu Dhabi's advertising placement manual [1] as a good example of how to manage roadside advertising.
\end{abstract}

\section{Introduction}

The advertiser's goal is to communicate a message or idea to the largest possible audience at minimal cost. Promoting products and ideas has been known for centuries. Competition generates brand building, requiring information on products, pricing and address data. One form of advertising is external advertising. Outdoor advertising is best used in places where the largest possible audience can see it, hence a natural location is by roads and streets.

In Poland after 1989 and the collapse of communism a free market began to emerge and this resulted in marketing activities, including the promotion of products. For nearly 30 years, there has been a continuous, practically unlimited practice of placing advertising at the roadside. The greater the traffic volume, the more willing the advertisers are to use this location for their advertising. It is standard practice to measure the traffic volume on multiple roads in order to situate advertising on the road with the highest possible traffic volume.

Public perception of outdoor advertising is becoming more negative due to the increasing density of advertising in public spaces and the lack of regulation that determines the location, form, content and aesthetics. There are many social movements that try to fight against advertising, especially those that represent the belief that advertisements deface the environment and are located illegally.

\footnotetext{
Corresponding author: tomasz.mackun@pg.gda.pl
} 
Unfortunately, for years in Poland, advertising has not been analysed as potentially distracting for drivers. Distraction may deteriorate driving performance. Therefore, it is thought that advertising can deteriorate road safety.

The answer to public demand for regulation of outdoor advertising is the so-called Landscape Act, i.e. the Act of 24 April 2015 amending certain acts. It strengthens landscape protection tools [2]. This law allows municipalities, under local law, to adopt resolutions which govern the conditions of advert placement and the collection of appropriate fees. Unfortunately, the Act [2] did not take into account the need to evaluate roadside advertising as objects that could distract drivers and pose a greater risk on the road.

Many countries prohibit roadside advertising, and others have implemented appropriate regulations. The examples are the Australian instruction guide [3], the Abu Dhabi manual [1], and the instructions for national roads in South Africa [4]. These instructions introduce rules that relate to road traffic safety. Their use is intended to minimise distraction, confusion or dazzling of drivers by advertisements.

\section{The Polish perspective}

In 1984 Poland ratified the European Agreement on Main International Traffic Arteries (AGR) [5], signed in Geneva on 15 November 1975, which prohibits the placement of advertisements on international roads. This regulation, however, is ineffective outside the boundaries of the carriageway. In Poland, regulations rarely refer directly to roadside advertising. More often, if an advertisement is considered a permanent structure on the ground, it is subject to building regulations. Unfortunately, these regulations rarely apply to traffic safety. While the Public Roads Act of 21 March 1985 [6] introduces regulations, it must be regarded as insufficient. This law regulates only the roadway and a small area in its vicinity. For drivers the boundary of the roadway is an invisible line. Existing regulations specifically regulate advertisements on the carriageway, however the placement of adverts immediately adjacent to the roadway is not regulated at all. The Act [6] forbids the placement of adverts on the carriageway outside built-up areas but allows for locating them on the carriageway in built-up areas. The rule prohibits the placement of advertisements that imitate traffic signs, markings and traffic safety devices. Unfortunately, the rules do not mention motorist distraction. The amendment to the Act on Public Roads [6], in connection with the Landscape Act [2], introduces regulation for off-carriageway advertising at a distance in accordance with Table 1, in terms of light emission, display of animated images, visual effects, gaps between successively displayed information and also minimum display of visual information presentation of 10 seconds. Unfortunately, the distance shown in Table 1 is insufficient for most roadside advertising to be affected. "The Regulation of the Minister of Infrastructure and Development [7] of 20 October 2015 on the technical conditions to be met by level crossings and their location" prohibits the placement of advertising within the visibility triangles and on a section of $20 \mathrm{~m}$ from each side of the level crossing, as well as on railway viaducts within the area of the roadway.

The Act [8] on the Road Traffic Law prohibits "the placing of objects that emit or reflect light within the road boundaries in a way that may blind road users or mislead them." The provision of this law is appropriate but very difficult to enforce. There is also no provision for banning devices that may distract or mislead drivers.

The Convention on Road Signs and Markings [9], drawn up in Vienna on 8 November 1968 which the Polish Government ratified specifies that "[...] parties take measures to prohibit placement of boards, posters, signs or devices that can be confused with signs or other traffic management devices, or may reduce their visibility or efficacy, or dazzle the road users or distract them in ways that threaten road safety [...]". This is the only document 
that mentions driver distraction but secondary legislation within this scope was not implemented.

Table 1. Distance from the road boundaries where advertising cannot be located.

\begin{tabular}{|c|c|c|c|}
\hline No. & Type of road & In built-up area & $\begin{array}{c}\text { Outside built-up } \\
\text { area }\end{array}$ \\
\hline 1 & Motorway & $30 \mathrm{~m}$ & $50 \mathrm{~m}$ \\
\hline 2 & Express Road & $20 \mathrm{~m}$ & $40 \mathrm{~m}$ \\
\hline 3 & General Access Road: national & $10 \mathrm{~m}$ & $25 \mathrm{~m}$ \\
\hline 4 & General Access Road: voivodeship, & $8 \mathrm{~m}$ & $20 \mathrm{~m}$ \\
\hline 5 & General Access Road: municipality & $6 \mathrm{~m}$ & $15 \mathrm{~m}$ \\
\hline
\end{tabular}

The Landscape Act [2] allows municipalities to adopt local advertising placement rules and gives them the power to set rules, collect charges and create media free zones. The advantage of this procedure is the ability to impose large penalties and the enforcement process is quick. So far, implementing the Administrative Procedure Code has meant that the process of removing illegal advertising or imposing penalties has been so slow that advertisers often pay penalties and continue to make significant profits from illegal advertising, or by using procedural deadlines, drag the administrative process indefinitely.

The drawbacks associated with the Landscape Act are:

- Each municipality (gmina) will adopt different regulations, so that for the driver travelling across the country, roads and their adjacent areas will be governed by different standards;

- Many municipalities may pass legislation without taking into account the need to ensure road safety;

- Road authorities are not party to the proceedings in the process of passing local law, so a resolution of the municipality will be implemented without the opinion of the road authorities;

- Municipalities may allow as many advertisements as possible to maximise their revenue from fees.

Currently, drafts of landscape resolutions are being prepared in Poland. Observations conducted in large cities: Warsaw, Cracow, Lodz and Gdansk indicate that only Gdansk and Lodz have taken traffic safety into account, although to a very limited extent.

Bearing in mind the above, it should be noted that advertising regulations in Poland are substantial but insufficient, scattered and difficult to enforce. Some rules do not exist and it is justified to create a comprehensive advertising placement guide.

\section{Foreign perspective - the example of Abu Dhabi}

The authors have analysed a number of instruction manuals and guides that govern the location of advertising media and how they are displayed. It was decided to present the scope of one of the manuals issued by the Department of Transportation for Abu Dhabi City, [1] which, although not free from minor shortcomings, presents a consistent set of rules for media divisions, locations, parameters and content.

This instruction applies to all advertising visible from the road at a distance of $300 \mathrm{~m}$ from its edge. This is very important. In Poland many provisions are valid but the scope of action is very limited. Abu Dhabi adopted the following advertisement classification:

- billboards, 
- flags and banners,

- advertising on the carriageway,

- urban furniture,

- mobile advertising,

- other advertising,

- sign boards.

Depending on the type of advertisement, different rules have been introduced, but regardless of the type they cannot:

- present content imitating signalling or traffic signs,

- be mounted on signs or road sign structures,

- be brighter than traffic lights,

- present content that is not completely legible or visible from the road,

- contain more information than can be "read/understood" during two short glances,

- be mounted over carriageways,

- be installed in a central reservation separating carriageways on motorways,

- be mounted near intersections or junctions,

- be assembled in groups,

- contain distracting content,

- have visible light sources,

- have moving and rotating elements,

- emit the sound or smell that the motorists could detect.

Depending on traffic volume and speed limits, so-called "free zones" should be used, where the structure of the advertisement should not be located in a position where there is a risk of vehicle impact that may run off the road. The minimum distance is $3 \mathrm{~m}$ and the maximum is $9 \mathrm{~m}$.

The advertisement exclusion zones have been used in this manual, i.e. it is recognised that in some areas the advertisements should be eliminated to ensure that motorists can focus on driving tasks. Exclusion zones were used in the area of intersections (Fig. 1), roundabouts, junctions and exits. The exclusion buffer is calculated differently at the approach to the collision point (zone B) and differently when exiting the collision point (zone A). When exiting the collision zone, ads cannot be located within a distance dependent on speed and the number of units of information contained in the ad. The more information and the higher the speed, the longer the ad-free stretch should be. An ad-free buffer at the approach to the collision point depends only on speed. For example at $50 \mathrm{~km} / \mathrm{h}$ the buffer is $42 \mathrm{~m}$, for 100 $\mathrm{km} / \mathrm{h}$ it is $83 \mathrm{~m}$.

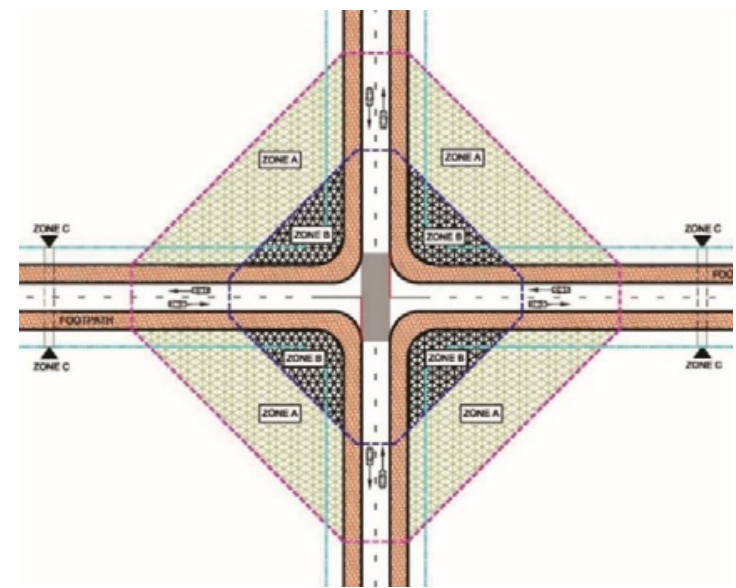

Fig. 1. Cross Intersection Advertisement - free Buffer Zone [1]. 
The permit is for a specific time and does not exceed 3 years. The application process as presented in Fig. 2 is also noteworthy. The predetermined application is checked for national and local regulations. In case the application is invalid the applicant has 30 days to amend the application. If the application is submitted correctly and the parameters of the advertisement comply with all the regulations, a clerk performs a check in the field. Once the application complies with the site requirements, the terms and conditions and length of contract with the advertiser are determined. The permit is for a specific time and does not exceed 3 years.

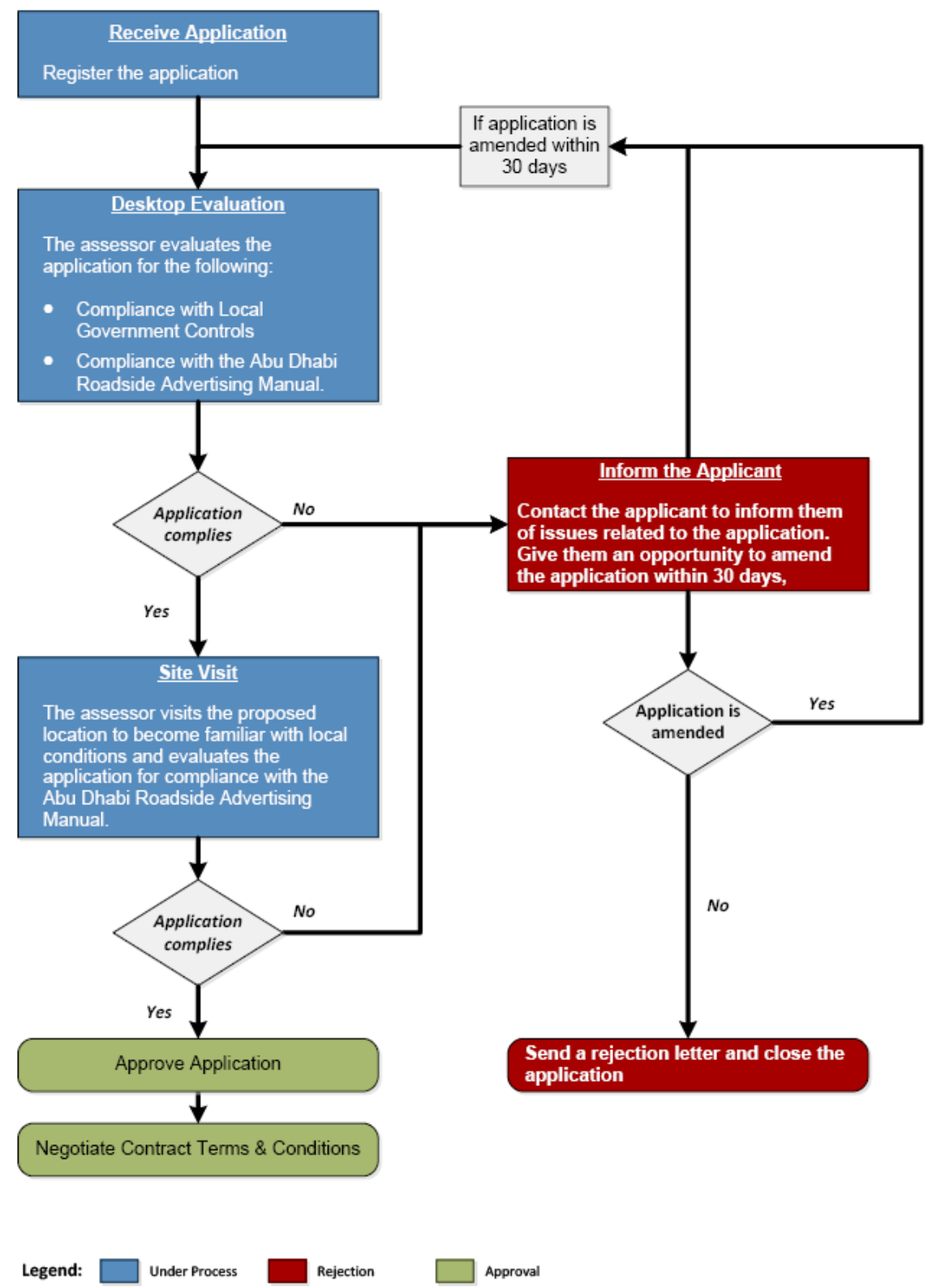

Fig. 2. Procedural Flowchart for Permit Application Review [10]. 


\section{Conclusions}

The authors are aiming to develop their own instruction guide for locating and displaying advertisements on national roads. Ultimately, it is recommended to regulate the location and display of advertising on all roads in Poland in order to achieve a high level of traffic safety. Work is underway to assess hazards resulting from driver's distraction caused by roadside advertising [10][11]. In addition, a review of Polish regulations and foreign instructions is conducted. According to the authors, the following principles should constitute the basic principles for the development of instructions regulating the placement and the form of advertising on roads in Poland:

- Advertising does not jeopardize the level of road safety by rule. Advertising can pose a risk of reducing traffic safety if it is located where drivers should focus primarily on driving tasks or where the form of the advertisement (size, lighting or content) will draw the driver's attention for too long.

- The spatial extent of the regulation should not be related to the roadway boundary. The scope of the contract should include all advertisements that are visible from the road and which may affect motorists.

- If motorists are exposed to advertising, its content should be governed with the same approach as road signs. When advertising is displayed, its form and content should be such that the motorist will read and comprehend it within 2-3 seconds.

\section{Acknowledgements}

Research conducted under a project implemented within RID programme, funded by the Polish National Centre for Research and Development and the General Directorate for National Roads and Motorways in Poland, for the years 2016-2019.

\section{References}

1. Roadside advertising manual, Document No: AD-R-03 First Edition (Abu Dhabi, 2013)

2. Act of 24 April 2015 amending certain acts on strengthening the tools for landscape protection, OJ 2015 Pos. 774 (Poland, 2015)

3. Guideline: Roadside Advertising Guide, Edition 1.2 (Departament of Transport and Main Roads, Australia, 2013)

4. The South African National Roads Agency limited repeal of certain regulations and making of regulations (The South African National Roads Agency, 2000)

5. European Agreement on main international traffic arteries (AGR) (Poland, 1985)

6. Act of 21 March 1985 on Public Roads, OJ 2007 No. 19 Pos. 115 (Poland, 1985)

7. Regulation of the Minister of Infrastructure and Development of 20 October 2015 on the technical conditions to be met by the crossings of railway lines and railway siding with roads and their location, pos. 1744 (Poland, 2013)

8. Act of 20 June 1997 Road Traffic Act no. 98 pos. 3113 (Poland, 1997)

9. Convention on Road Signs and Markings (Vienna, 1968)

10. T. Mackun, K. Jamroz, J. Żukowska, J. Rychlewska, Zagrożenia dla uczestników ruchu drogowego stwarzane przez reklamy widziane z drogi, Drogownictwo. 4-5 pp. 134$141(2015)$

11. K. Jamroz, T. Mackun, J. Rychlewska, J. Wachnicka, Reklamy widziane z drogi: pomagają czy przeszkadzają kierowcom?, in: Cracow Road Saf. Days, (2015) 